\title{
Conceptual model assessing complex the public-private partnership projects effectiveness
}

\author{
Margarita Panteleeva*, Denis Surnov, and Dmitry Senchukov \\ Moscow State University of Civil Engineering, Yaroslavskoe shosse, 26, Moscow, 129337, Russia
}

\begin{abstract}
The article presents the author's model assessing complex the public-private partnership (hereinafter PPP) projects effectiveness based on the multifaceted development of this tool for the development of regional economic systems. The relevance of the research topic is since accelerating the pace of fundraising, expanding the range of possible options for publicprivate partnership agreements, increasing the number of innovative projects increase the problem of developing comprehensive criteria for the PPP effectiveness assessing. Most modern studies are rather narrow in nature and consider only one of the aspects of the development of a PPP instrument: the mutually beneficial union of public and private capital. In this regard, the presented study purpose is to develop a conceptual model for the PPP projects effectiveness comprehensive assessment. The sources of this work are the regulatory legal Russian Federation acts in the field of public-private partnerships, the works of domestic and foreign authors in this area, as well as official information pages from the Internet. The developed model includes three stages of efficiency assessment. At the first stage, a qualitative PPP project assessment is carried out. The principles of integrated PPP projects assessment future model are being formed. The risks are to identify in a PPP project for each stakeholder. The second stage analyzes the value of partnerships. This analysis is based on an assessment of various comparative project performance kinds. At the third stage, a three-aspect assessment of the project's effectiveness is carried out, considering the potential social result from the project and the benefits of the state and private partners. Based on this, the practical significance of the proposed integrated assessment model is determined, both in the regulations development to justify and the individual PPP projects effectiveness.
\end{abstract}

\section{Introduction}

In the modern world, public-private partnership is widespread and is an effective tool for solving such strategic the national economy tasks as:

- insufficient budgetary funds to ensure stable economic development and a high standard living the population;

- $\quad$ stimulating competition in socially significant sectors:

*Corresponding author: PanteleevaMS@mgsu.ru 
- combining the state and the private sector of the economy human, technological, financial resources, and achieving their interaction synergistic effect;

- ensuring parity in the region's development, etc. [1].

In the modern sense the public-private partnership mechanisms development in Russia began in the 1990s. The "turning point" was the Federal Law No. 224-FZ of July 13, 2015 "On public-private partnership, municipal-private partnership in the Russian Federation and certain legislative amendments to them the Russian Federation acts" [2].

The data in Figure 1 indicate the active PPP development in Russia [3]. This is confirmed by the number of simultaneously implemented PPP projects over the past 10 years, which has increased more than 15 times (Fig. 1). Currently, the public-private partnership market in the Russian Federation has 3,656 projects with a total investment of 3.9 trillion rubles (this is $1.7 \%$ of GDP), of which 2.8 trillion rubles are private funds of investors.

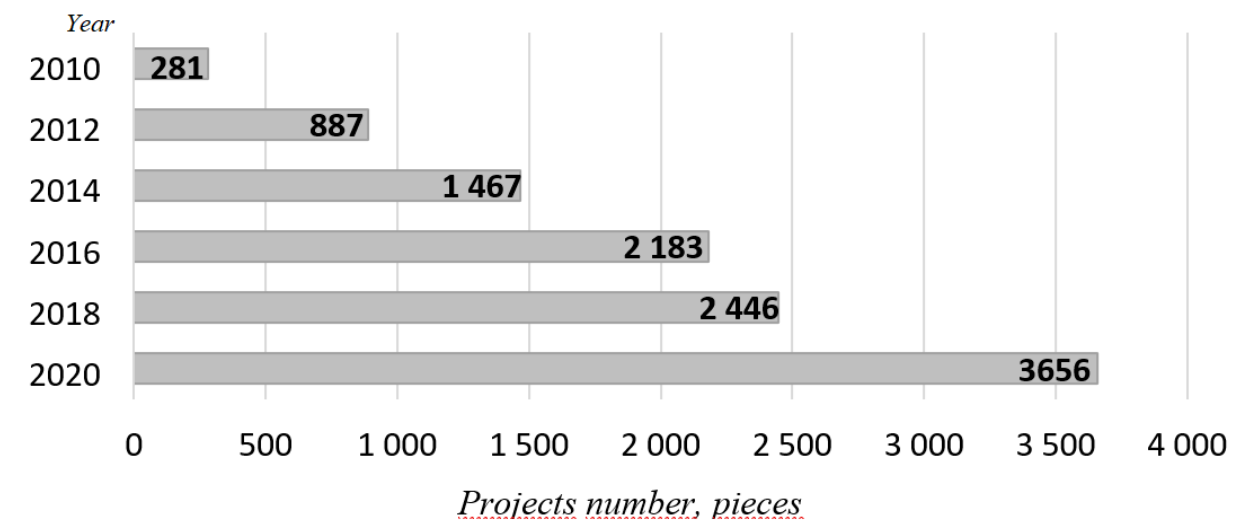

Fig. 1. The PPP projects number implemented in the Russian Federation in 2010-2020 [compiled by the authors based on 2].

The public-private partnerships development in the Russian Federation is gradually taking over new the country's economy sectors. To date, the PPP is most popular tool has become for the social sphere, transport and utilities and energy sector (Fig. 2).

Figure 2 shows that the absolute leader in the projects number is the utilities and energy sector ( $87.6 \%$ of all PPP projects in the country). This fact corresponds to the main declared by the state of the public-private partnership goal: the course towards the system development of providing quality public goods $[2,4]$.

The first half of 2020 was held for the Russian economy under the coronavirus pandemic influence. This affected the price characteristics of the main oil refining industry products. However, the market for PPP projects has not stopped in its development. This can be explained by the fact that the market for ongoing PPP projects is practically inelastic to such crises in the economy. It is impossible to speak about absolutely stable this segment dynamics, but it is also impossible to state the absence of business activity or outflow of investments. These facts indicate the need for further PPP mechanisms development [5], as supporting a country economy instrument.

In connection with the above facts, the article authors formulated a problem that does not allow expanding the number of stakeholders and concluded PPP projects in the Russian Federation. This problem is associated with the absence in the PPP practice using a multicriteria approach to assessing the proposed projects effectiveness, considering the multifaceted nature of the process under consideration. 


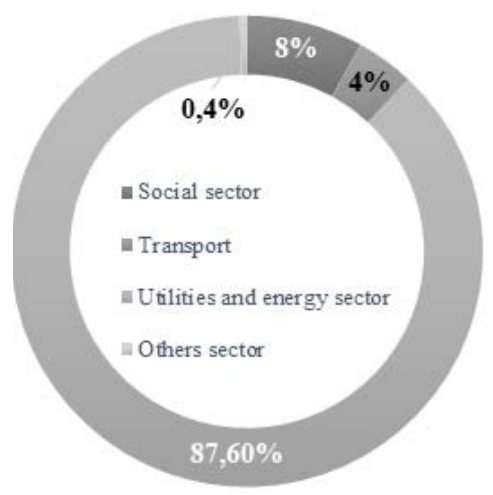

Fig. 2. PPP projects distribution in the Russian Federation by economic sector in 2020 , in $\%$ of the total number of PPP projects in the country [compiled by the authors based on 2].

In connection with the above, the study presented purpose is to develop a conceptual model assessing complex the public-private partnership projects effectiveness.

The research objectives, respectively, are:

- analysis of methods for assessing the PPP projects effectiveness in order to identify their "weaknesses";

- substantiation proposals on creature the main elements the complex assessment model effectiveness;

- the prospects forecast the implementation of the complex assessment model effectiveness.

\section{Methods}

To mitigate this problem, are consider the methodologies for evaluating PPP projects. Most of the scientific studies $[1,3,4,5,6,7,8,9]$, devoted to PPP, are rather narrow in nature and consider only one of the PPP projects evaluation aspects. Therefore, these methodologies limit the PPP projects effectiveness assessments. If we generalize the methodological approaches to assessing the PPP projects effectiveness for the last five years proposed in the research works, then we can distinguish three aspects of its implementation:

1) legal aspect. Considers the evaluating effectiveness problems exclusively in the eliminating legislative gaps context [7];

2) socio-economic aspect. Considers PPP projects as an element of regional development and does not separate its effectiveness from the state or municipal policies effectiveness aimed at meeting the society needs in a normal life environment [10];

3) financial aspect. Gives recommendations for assessing the financial PPP projects efficiency $[6,8,10]$ only through the analyzing social effects prism $[8,9]$. In addition, studies, including those initiated by state or international organizations, analyze the financial component and, accordingly, the evaluating PPP projects effectiveness on the level of a separate territorial [7] or industry segment. Conclusion there is no general approach to assessment.

Let us turn to the institutional foundations public-private partnerships to determine the criteria for assessing its efficiency, since the PPP essence should become the basis for developing a assessing efficiency model.

To do this, is define a public-private partnership as a voluntary agreement concluded between the "state" (public partner) and a private economic entity - "business" (private partner) for the medium (long) term and assuming the sharing of risks, costs and benefits in the process of creating and(or) subsequent socially useful objects exploitation [4]. 
A key aspect of PPP development is the voluntariness of participation in the project (which is especially important for a private partner) and mutual economic interest. That is, each of the parties pursues its own benefits (see Fig. 3), the possibility of realizing which determines their interest in PPP projects [8].

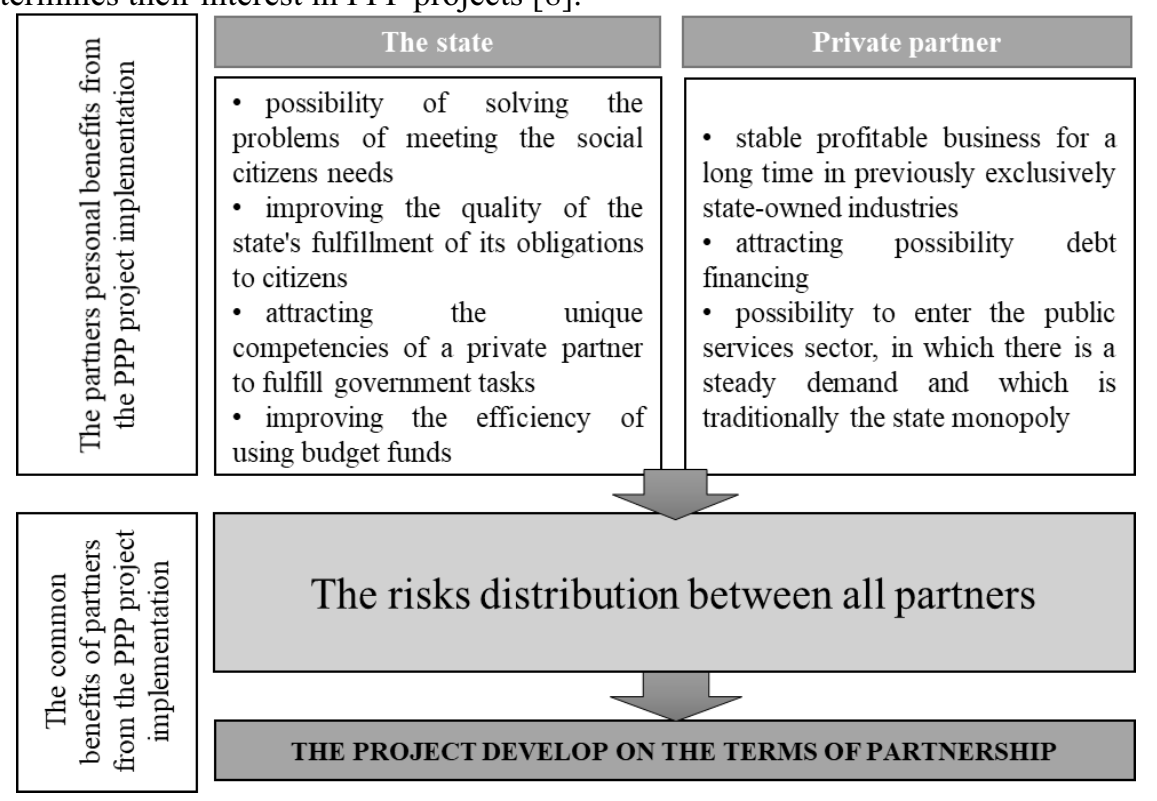

Fig. 3. Kinds of benefit for sake for partners when participating in PPP projects. [created by the authors].

The private partner in most cases evaluates the possibility of making a profit, that is, in fact, compares the result of investing in a public or private project and analyses the PPP project effectiveness at the pre-project stage, at the project implementation and in the project completion (Fig. 3) [9].

The state, which is the initiator of most of the projects, the effectiveness assessment should be carried out at an earlier stage (before the presentation of the project) and according to a comprehensive scheme.

The scheme should include the need to consider both qualitative and quantitative indicators, both economic and social effects (Fig. 3).

In practice, the PPP projects effectiveness assessment is carried out as part of the project implementation method substantiation. The PPP projects effectiveness assessment is carried out by authorized bodies in accordance with the Russian Federation Government Decree of December 30, 2015 No. 1514 "On the procedure for an authorized body to assess the private partnership project effectiveness" [11].

In its most generalized form, this methodology assumes that the project is recognized as effective from an economic point of view if the following condition is met (1):

$$
N P V_{g}=-I C+\sum_{t=0}^{N} \frac{C F_{t}}{(1+R)^{t}} \geq 0, \quad \text { for } R=\frac{C A+C D}{C I}
$$

where $N P V g$ - net present value of the government's "cash flows" from the PPP project; $t$ year of the PPP project implementation (in years); $N$ - total number of years of the PPP project implementation (in years); CFt - "cash flow" of the authorities on the the PPP project implementation for the period $t$; IC - initial investment in the PPP project (public and/or 
private investment); $R$ - discount rate (cost of state (municipal) resources); $C A$ - expenses for the administration of taxes and fees; $C D$ - public debt service expenditure; $C I$ - the total amount of all budgetary expenditures allocated to investment projects.

The net present value of the authorities "cash flows" from the project must be either greater than zero or equal to zero. In the latter case, it is assumed that the project zero financial efficiency is offset by a positive social effect. The positive social effect is assessed by the fulfillment of two conditions:

1) the PPP project goals and objectives must correspond to at least one goal (task) of state (municipal) targeted strategic programs in the area;

2) the PPP project target indicators must correspond to at least two target indicators of state (municipal) target strategic programs in this area.

In addition, the approved state methodology for evaluating PPP projects involves comparing the chosen project implementation method only with a direct state order [9].

Currently, this methodology disadvantages number have become apparent [6]:

1) a formal approach to comparing options for public-private partnerships and direct government orders;

2) there is no required criteria number for the project efficiency social aspects qualitative analysis.

\section{Results}

With all the variety of PPP forms, at their core, they are designed to provide a certain benefit for stakeholders each. At the same time, the expected effect may lie in different areas for the stakeholders each and have different criteria related not only to the area of financial indicators.

The approach development to assessing PPP projects effectiveness involves the study of this phenomenon and the analysis of the main management components: project effectiveness and partnership itself assessment, its value and feasibility.

The article authors propose to present the PPP project effectiveness assessment in the form a sequence from the three stages:

Stage 1. Qualitative PPP project assessment.

Stage 2. Analys of the value of partnerships based on effectiveness different types.

Stage 3. The PPP project effectiveness evaluation.

The proposed stages content is given in the author's conceptual model for a PPP projects effectiveness comprehensive assessment, presented in Figure 4.

Stage 1. Qualitative PPP project assessment. At this stage, a generalized system of basic principles is formed that determine the feasibility, validity, and possibility of organizing PPPs to ensure the growth of the investment potential of projects and regional development programs. The system of principles is as follows [3]:

1. The principle of mutual interest - the effect of interaction is maximum if each of the parties sees the possibility of achieving their own goals only with the assistance of the other.

2. The principle of parity of interests - one of the parties does not set itself the goal of persuading the other side to interact against its will or to the detriment of its interests [12].

3. The principle of strategic regulation of social consequences - measures that are implemented within the framework of PPP should be focused on ensuring the achievement of strategic goals of not only economic, but also social development of the region [13]. 


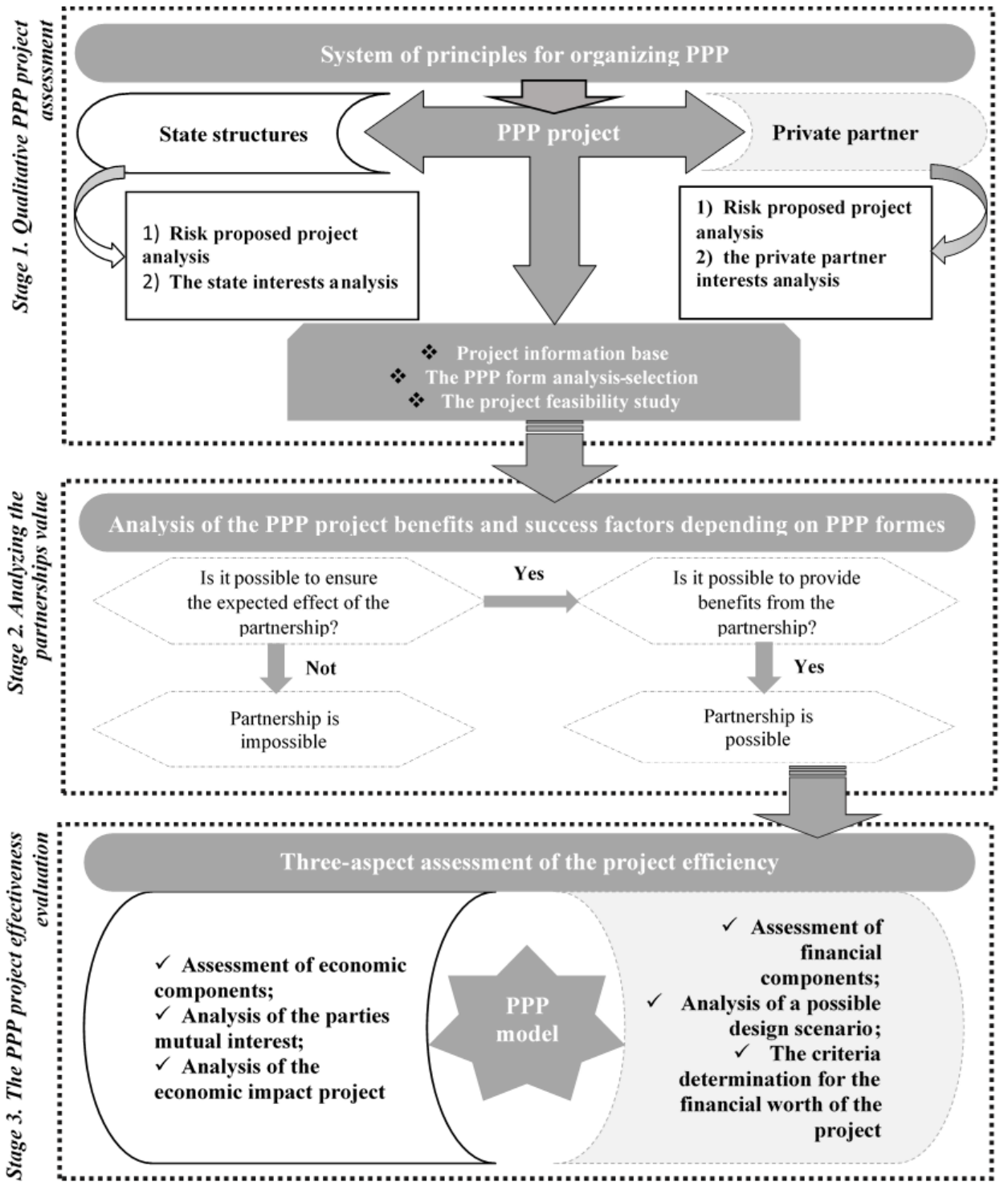

Fig. 4. Conceptual model assessing complex the PPP projects effectiveness [created by the authors].

Further, at the first stage, a risk analysis is carried out for both project participants. For the state, the following risks are identified as the most significant [14]:

- technical errors at the stage of project development for procurement of material resources;

- choosing an irrational PPP form;

- bad faith on the part of a private partner;

- low quality of services provided to consumers by a private partner.

For a private partner, the set of risks can be divided into four large groups [15]:

1. Risks arising from the activities of state authorities.

2. Risks associated with the participation of the state as a partner in PPP projects.

3. PPP projects business risks. 
4. Risks associated with protests by the population, public and international organizations.

At the same stage, an information base about the PPP project is formed. The information base includes the following main elements [8]:

1. The problems description to be solved because of PPP implementation.

2. Information about the object of partnership, indicating its main characteristics.

3. The PPP project goals and planned results, as well as ways to achieve them.

4. Information about PPP participants.

5. Forms of PPP implementation.

Based on the data obtained, a feasibility study of the project is being developed. A PPP feasibility study should conclusively demonstrate that the proposed project is more attractive than a traditional public sector projects. The following factors should be considered:

- the specific results to be achieved during the implementation of the project must be known and agreed with the stakeholders, and they must be precisely defined and suitable for measurement and monitoring;

- technological and other relevant aspects are reasonably stable; the contract does not need to be constantly adapted to changing environmental conditions;

- the private sector has potentially better ability or skills than the public sector to carry out the project and provide the necessary services;

- a high level of competition is expected when submitting applications for the implementation of a PPP project [9].

Thus, the qualitative assessment criteria include: the presence of a private investor, the strategic importance of the project, the presence of positive social effects, the impossibility of implementing the project without state support, a positive expert opinion.

Stage 2. Analyzing the partnerships value. At this stage, conclusions about the value of partnerships are formulated based on the various kinds of comparative effectiveness presented in Figure 5.

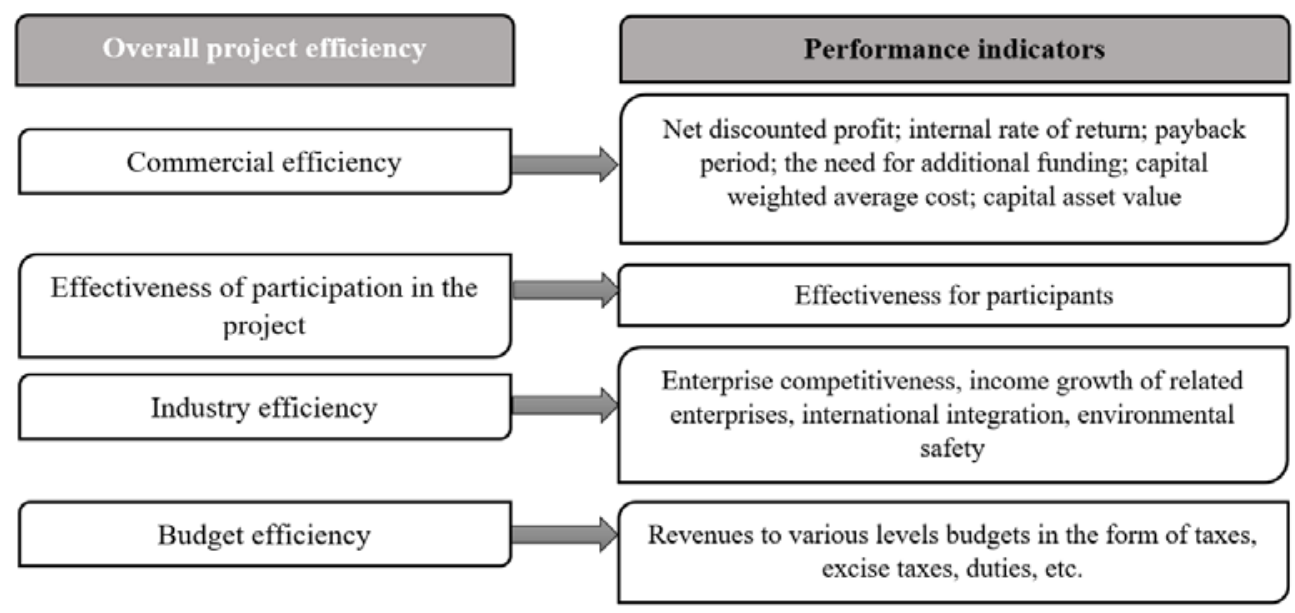

Fig. 5. Kinds of comparative PPP projects effectiveness [created by the authors].

For a direct assessment of the comparative effectiveness of PPP projects, depending on the complexity of the project, various methods and tools are used, from the simplest calculations to the most complex analysis, presented in Table 1.

Determining the effectiveness of PPP participants, based on comparing actual results with planned ones, deviations are recorded, and their causes are established, changes in the socioeconomic environment are monitored and the prospects for further implementation of projects are predicted. At the same time, such monitoring should include feedback, based on 
which the adjustment of PPP projects will be carried out, which will contribute to the formation of more substantiated management decisions and increase the efficiency of regional management of PPP projects, including pricing and tariff policy.

Table 1. Methods for assessing the PPP projects comparative effectiveness depending on the level of complexity [9].

\begin{tabular}{|l|l|l|}
\hline Difficulty level & Method name & Comparison base \\
\hline Lower & Competitive bidding procedure & Other PPP projects \\
\hline \multirow{3}{*}{ Middle } & $\begin{array}{l}\text { The Public Sector Comparator (PSC) is a tool } \\
\text { used by the government in determining the } \\
\text { appropriate service provider for a public } \\
\text { sector project. It consists of an estimate of the } \\
\text { cost the government would pay if it provided } \\
\text { the service on its own. }\end{array}$ & $\begin{array}{l}\text { Before the selection } \\
\text { procedure for the } \\
\text { winner of the } \\
\text { competition }\end{array}$ \\
\cline { 2 - 3 } & $\begin{array}{l}\text { After the selection procedure for the winner of } \\
\text { the competition }\end{array}$ & Traditional project \\
\hline Highest & Complete cost-benefit analysis & Traditional project \\
\hline
\end{tabular}

Stage 3. The PPP project effectiveness evaluation. At this stage, an assessment of the economic, financial, and social effectiveness of the PPP project for the state and private business is carried out. For this, traditional and new indicators are used [6], for example, the growth rate of the net present value for all project stakeholders; the amount of positive annual financial flows from the project, etc.

\section{Discussion}

Summarizing the above, it can be noted that the accumulation of an information base on the PPP practice, an increase in the number of options for PPP agreements, an increase in the number of projects and the volume of attracted funds necessitate the development of new approaches for assessing the PPP projects effectiveness.

The methodology for evaluating PPP projects, enshrined in the Decree of the Government of the Russian Federation No. 1514, considers the evaluation procedure from two sides. On the one hand, the PPP projects assessment by business structures contributes to the formation of an information base for subsequent assessments. On the other hand, the state methodology $[2,16,17,18]$ for assessing the PPP projects effectiveness allows comparing the risks and PPP benefits on a par with direct budget financing, as well as assessing social effectiveness. But it lacks mechanisms for comparing different options for PPP agreements, and it is also impossible to assess social effectiveness in the long term. Some stages of the state methodology in the information base absence on previous projects cannot be carried out objectively. Therefore, the Russian Federation Ministry methodology of Economic Development remains incomplete.

To clarify this methodology, according to experts [9, 19, 20, 21, 22], it is advisable:

1) conduct a detailed assessment of the project's feasibility. This will help identify hidden risks and potential barriers to project implementation;

2) pay attention to assessing the project social feasibility;

3) to monitor the social climate, so that will prevent social tension.

The model proposed in this article considers the opinions of experts in the PPP project management. A PPP project that has passed all the stages of the proposed integrated assessment model is likely to meet not only the tasks of saving budget funds, but also the strategic goals of state policy. The proposed model is aimed at considering in the project final 
version the interests of not only the state, but also the private partner, which will further expand the circle of potential private partners interested in implementing the approved PPP project.

However, the author's model takes time for a detailed elaboration and search for adaptation criteria for its application in various directions of government activity.

\section{Conclusions}

Summing up, we can say that the conceptual model assessing complex the public-private partnership projects effectiveness proposed in this article allows you to form the most beneficial interaction between the state and the private sector. This model, with its competent adaptation and regulation, can become an effective tool for identifying partners for PPP, both for the state and for business.

It should also be noted that the presented author's model has both scientific-theoretical and practical significance, since it can be used as:

- the basis for further development of the legal framework for PPP, in terms of improving the methodology for assessing the PPP projects effectiveness;

- an algorithm for developing a strategy for the PPP development in the Russian Federation, as it allows you to assess various aspects of the projects effectiveness, and, therefore, the direction of development of the PPP institution itself;

- recommendations for predicting the PPP projects effectiveness already at the initiation stage

\section{References}

1. V.V. Gasilov, A.V. Parinov, Ekonomika v investicionno-stroitel'nom komplekse i ZHKKH. 1 (15) 12-17 (2018)

2. Federal'nyj zakon ot 13.07.2015 № 224-FZ (Electronic Materials: https://duma.consultant.ru/documents/3703536) (2019)

3. P.A. Gagarin, E.A. Dvinyanin Gosudarstvenno-chastnoe partnerstvo kak instrument realizacii masshtabnyh proektov. Analiticheskoe issledovanie, 14 marta 2013 (Electronic Materials: https://www.gradient-alpha.ru/) (2013)

4. V.E. Sazonov Gosudarstvenno-chastnoe partnerstvo $v$ Rossii $i$ za rubezhom: administrativno-pravovoe issledovanie: avtoreferat, d-ra yurid. nauk. Moskva, (2013)

5. Rekomendacii po realizacii proektov gosudarstvenno-chastnogo partnerstva. Luchshie praktiki. Ministerstvo ekonomicheskogo razvitiya RF. Moskva (Electronic Materials: https://investugra.ru/upload/iblock/1e0/metodic2018.pdf) (2018)

6. V.A. Grebennikova, I.L. Gryada, Sovremennaya nauka: aktual'nye problemy teorii i praktiki. Seriya: Ekonomika i pravo. 6 19-25 (2019)

7. A.K. Bahmatova, Vestnik nauki i obrazovaniya. 7(43), T.1, 29-30 (2018)

8. Prikaz Minekonomrazvitiya Rossii № 894 ot 30 noyabrya 2015 (Electronic Materials: https://www.economy.gov.ru/material/dokumenty/prikaz_minekonomrazvitiya_rossii_8 94_ot_30_noyabrya_2015_html) (2017)

9. Postanovlenie Pravitel'stva RF ot 30 dekabrya 2015 g. N 1514 (Electronic Materials: https://base.garant.ru/71296434/) (2018)

10. Federal'nyj zakon ot 21 iyulya 2005 g. № 115-FZ (Electronic Materials: https://base.garant.ru/12141176/) (2020) 
11. S.A. Barkalov, L.A. Mazharova, Ekonomika i menedzhment sistem upravleniya. 4(30) 410 (2018)

12. N.B. Grosheva, M.S. Nujkina, E.S. Glasova Konkurentosposobnost' v global'nom mire: ekonomika, nauka, tekhnologii. 3-1 (32) 28-30 (2017)

13. D. Delmon D. Gosudarstvenno-chastnoe partnerstvo v infrastrukture: prakticheskoe rukovodstvo dlya organov gosudarstvennoj vlasti, Astana, s. 2-6 (2010)

14. M.S. Panteleeva, Ekonomika i predprinimatel'stvo. 3-2 (80) 865-868 (2017)

15. M.S. Panteleeva, A.A. Dmitriev Upravlenie riskami pri realizacii investicionnostroitel'nyh proektov s pomoshch'yu metodov prognozirovaniya, v sbornike: Upravlenie proektami: kar'era i biznes. Materialy Vserossijskoj nauchno-prakticheskoj konferencii, GUU, Moskva, 14-15 maya 2019, s. 123-126 (2019)

16. D.D. Klykanov, Gosudarstvenno-chastnoe partnerstvo. 3(4) 179-196 (2017)

17. M. Panteleeva, S. Borozdina. MATEC Web of Conferences 193, 01011 (2018)

18. M.S. Panteleeva, D.E. Senchukov, Ekonomika i predprinimatel'stvo. 12 (125) 804-807 (2020).

19. M.S. Panteleeva, Ekonomika ustojchivogo razvitiya. 2 (42) 171-175 (2020)

20.S. Borozdina, A. Dement'eva, IOP Conference Series: Materials Science and Engineering. 869, I. 6, 062015 (2020)

21. M. Panteleeva, IOP Conference Series: Materials Science and Engineering. 869, I. 6, 062032 (2020).

22. Ocenka effektivnosti proektov GCHP po sravneniyu s inymi formami realizacii infrastrukturnyh proektov $v$ stranah-uchastnicah EAES: analiticheskoe issledovanie Nacional'nogo centra GCHP, YAnvar' 2017, Russia, Moskva, (Electronic Materials: http://www.eurasiancommission.org/hy/act/finpol/dobd/ppp/Documents/issledovanie_1 00118.pdf) (2018) 